\title{
Transcription Cofactor HES-6
}

National Cancer Institute

\section{Source}

National Cancer Institute. Transcription Cofactor HES-6. NCI Thesaurus. Code C104535.

Transcription cofactor HES-6 (224 aa, $\sim 24 \mathrm{kDa}$ ) is encoded by the human HES6 gene.

This protein plays a role in the modulation of transcription factor activity. 